Aftenpostens dekning av de norske soldatenes innsats i Afghanistan gir et ukritisk og uklart bilde av soldater i krig.

\title{
Den norske militære godteposen
}

Irene Elisabeth Rossland (f. 1975) er journalist i nyhetsavdelingen i NRK. Hennes hovedfagsoppgave i journalistikk heter: «Den norske militære godteposen. En analyse av Aftenpostens dekning av Norges deltakelse i krigen i Afghanistan». Skrevet ved Universitetet i Oslo (2006). 
TEKST: Irene Elisabeth Rossland

FøRST FIRE ÅR ETTER at norske styrker dro til Afghanistan for å hjelpe usa i "krigen mot terror", innrømmet myndighetene at norske soldater hadde tatt fanger i Afghanistan. Myndighetene innrømmet samtidig at de ikke hadde oversikt over hvor mange krigsfanger norske styrker hadde tatt.

Hemmeligholdet rundt hva de norske soldatene faktisk gjorde i Afghanistan, preget mediedekningen av den norske deltakelsen i denne krigen. Daværende utenriksminister Jan Petersen avviste kritikken om informasjonstørke og mente offentligheten ikke trengte ytterligere avklaringer om hva soldatene foretok seg i Afghanistan. Petersen mente det norske folk fikk vite det de hadde behov for, og stilte seg uforstående til kravet om mer informasjon: "Vi kjenner de norske sol- datenes oppdrag meget godt: de rydder miner og bekjemper terrorisme (...)". Men hva innebærer det å bekjempe terrorisme?

Jeg vil argumentere for at hemmeligholdet rundt hva de norske soldatene faktisk gjorde i Afghanistan, preget Aftenpostens dekning av den norske krigsdeltakelsen. Jeg vil også vise at Aftenposten støttet en norsk militær deltakelse i Afghanistan, og at myndighetenes argumentasjon for deltakelsen fikk stort gjennomslag i avisen. Til tross for at Aftenposten var kritisk til deler av krigføringen, ble denne kritikken behandlet separat fra avisens dekning av den norske deltakelsen i krigen.

Funnene er hentet fra hovedoppgaven min i journalistikk, der jeg analyserte artikler i Aftenposten om den norske deltakelsen i krigen i Afghanistan. Analysen omfatter redaksjonelt stoff i perioden fra terrorangrepene mot usA fant sted og ut påfølgende år (II. september 200I-3I. desember 2002).

\section{Mobilisering}

7. oktober 200I startet USA og Storbritannia bombeangrepene mot Afghanistan. Bombingen var et svar på terrorangrepene på USA II. september. President George W. Bush' umiddelbare respons på terrorangrepene var å definere angrepene som krigshandlinger og erklære "krig mot terror". Ved å definere krigen som en "krig mot terror" åpnet Bush for en global krig uten grenser og uten et avgrenset tidsperspektiv. I en Tv-tale sa Bush at stater eller personer som ikke støttet opp om USAS kamp ble betraktet som sympatisører med fienden. Som NATO-medlem og USA-alliert, valgte norske myndigheter raskt side i det todelte verdensbildet Bush tegnet opp og 
imøtekom den amerikanske forespørselen om militær hjelp til "krigen mot terror".

Det norske bidraget i krigen var todelt: Norge deltok med styrker i den usA-ledede operasjonen Enduring Freedom, som ifølge Forsvarsdepartementet hadde som oppgave å nedkjempe Al-Qaidas terrornettverk, og i den internasjonale fredsstyrken International Security Assistance Force (ISAF). ISAF-styrkene hadde som hovedansvar å stabilisere situasjonen rundt den afghanske hovedstaden Kabul. Norges bidrag inkluderte blant annet spesialstyrker, transportfly, F-I6 kampfly og eksplosivryddere.

For første gang siden andre verdenskrig skulle norske styrker stå under et annet lands kommando. Hvilken betydning det kunne få for norske soldater å kjempe under amerikansk ledelse var noe uklart. Humanitære organisasjoner som Amnesty International Norge, mente norske myndigheter ikke sikret seg mot at norske

\section{Hemmeligholdet rundt hva de norske} soldatene faktisk gjorde i Afghanistan, preget mediedekningen av den norske deltakelsen $i$ denne krigen.

styrker kunne komme til å bryte krigens folkerett i Afghanistan. Organisasjonen begrunnet dette med at norske soldater som eventuelt tok fanger i Afghanistan, måtte overlevere disse til amerikanerne. Ifølge Amnesty International Norge bryter usA Genèvekonvensjonene både når det gjelder fangebehandling og ved å nekte en kompetent domstol å avgjøre deres fangestatus. Amerikanske myndigheter mener at fanger som blir tatt i Afghanistan ikke skal behandles som krigsfanger fordi Genèvekonvensjonene ikke gir beskyttelse til terrorister. Norske myndigheter mente derimot at fangene skulle bli behandlet som krigsfanger. Norske og amerikanske myndigheter vil derfor ha ulik definisjon av hvem som er å betrakte som "lovlig stridende". Brigader Svein Ødegården reiste spørsmålet om de norske soldatene $i$ en slik situasjon skulle følge norske eller amerikanske regler. Forsvarsministeren forsikret at norske soldater skulle følge norsk lov, men innrømmet samtidig overfor Amnesty Nytt at norske soldater måtte overlate eventuelle fanger til amerikanerne.

\section{Solidaritet og frykt}

For å avdekke om Aftenposten som medieorgan støttet eller var kritisk til en norsk militær deltakelse, er det viktig å analysere lederartiklene. Lederartiklene kan sies å ha stor betydning fordi de leses av de potensielt mest innflytelsesrike leserne med høyest utdannelse og sosial posisjon. Ledernes påvirkningskraft på opinionen er likevel begrenset, fordi lederne samtidig er den minst leste delen av avisen.

Samtlige av de aktuelle lederartiklene i mitt utvalg argumenterte for at Norge skulle sende norske soldater til Afghanistan, og det er verdt å merke seg at støtten var gjennomgående $\mathrm{i}$ hele perioden. Den eneste kritiske debatten som var synlig, både på leder- og nyhetsplass, var debatten om selve beslutningsprosessen. usa ble tilbudt norske styrker uten at saken hadde vært oppe for et samlet Storting. Aftenposten reiste spørsmålet om regjeringen alene kunne vedta å tilby usa militære styrker eller om saken måtte behandles i 
Stortinget, som opposisjonspartiene krevde.

Ut fra tidligere forskning på medienes rolle i krig var det et ventet funn at Aftenposten støttet opp om en norsk militær deltakelse. Flere studier viser at sikkerhetspolitikken i et land er reflektert og forsvart i de dominerende nasjonale massemediene. Samtidig har medieforskere påvist at opinionsklimaet har stor betydning for medienes dekning av en konflikt. Hvis eliten er uenig i en sak, vil debatten bli synlig i mediene, men hvis eliten står samlet bak en politisk beslutning, vil mediene i stor grad slutte opp om regjeringens politikk. Med unntak av Sosialistisk Venstreparti (sv) var det bred enighet på Stortinget om å tilby usA militær hjelp. Det var heller ingen tydelig motstand i befolkningen mot krigen. Opinionsklimaet tilsa derfor at Aftenposten ville omtale den norske deltakelsen i positive ordlag.

Det som likevel er oppsiktsvekkende, er at Aftenpostens argumenter i stor grad er identiske med myndighetenes retorikk for en norsk deltakelse i krigen. Ut fra en gjennomgang av pressemeldinger fra Statsministerens kontor og Forsvarsdepartementet etter II. september har jeg identifisert fem argumenter som myndighetene formidlet til mediene. Argumentene fikk godt gjennomslag i avisens lederartikler:

I) Norge bør vise solidaritet med USA. Dette argumentet ble viet størst plass i lederartiklene. Solidaritetsargumentet spiller på folks følelser. Aftenposten bygget opp under forestillingen om at Norge står i gjeld til usA, og at det denne gangen var vår tur til å stille opp for vår gamle venn som alltid har vært der for oss. To dager etter terrorangrepene fastslår Aftenposten: "Ekte solidaritet kan aldri være enveiskjørt”, og understreker at Norge må stille opp dersom USA ber om det.

2) Krigen har støtte $i$ folkeretten. Det folkerettslige grunnlaget ble i liten grad berørt av Aftenpostens lederskribenter, men de få gangene det ble vist til FNs resolusjoner var det for å bevise at det var riktig å gå til krig. Ingen av lederartiklene synliggjør for leseren at flere folkerettslige eksperter her hjemme var uenige $\mathrm{i}$ at krigen var i tråd med folkeretten.

3) Vi må stå sammen mot terrorismen. Aftenposten viser at "krigen mot terror" skaper en bred allianse av land som står sammen. Begreper som "samhold", "alliert" og "front" går igjen, begreper som appellerer til folks følelser. Aftenposten påpeker blant annet at "krigen mot terror" bringer usA og Russland tettere sammen, og at vi er vitne til en ny politikk i en endret verden. Avisen tegner et bilde av at krigen skaper et større "Vi", og at det er positivt at norske soldater deltar fordi det binder Norge til denne nye alliansen.

4) Terror er en trussel også for Norge. Argumentet får gjennomslag i flere av lederne, blant annet skriver Aftenposten at Norge må støtte krigen fordi amerikanerne og vi har et felles mål, å "hindre ny terror". Avisen påpeker at "krigen mot terror" også angår "vårt land og vår sikkerhet". Dette argumentet appellerer til følelsene, og kan ha skapt usikkerhet og frykt som førte til at folk støttet opp om regjeringens politikk.

En offisiell argumentasjon for norsk deltakelse som ikke fikk gjennomslag i Aftenpostens lederartikler er argument 5) Norske soldater er dyktige. Beskrivelsene av 
de norske soldatene er fraværende i lederartiklene, men fikk, som jeg vil vise nedenfor, derimot fullt gjennomslag i nyhetsartiklene om de norske spesialstyrkene.

\section{Forsvaret og pressen}

$\AA$ holde tilbake informasjon eller spre desinformasjon er en vanlig propagandastrategi myndighetene har benyttet i krigstid gjennom historien. Spesielt vil militære myndigheter prøve å holde tilbake informasjon om tap av sivile og feilbombinger. Det vil derfor alltid være en maktkamp mellom myndighetene og mediene i forkant av og under en krig. Journalistene vil ønske å få mest mulig informasjon og tilgang til krigsområdene, mens militæret som regel vil søke å ha mest mulig kontroll over hvordan konfliktene blir presentert. I Norge har pressen derimot fått kritikk for å ha for tette bånd til Forsvaret. Etter at Norge fikk sin selvstendighet i I905, forventet norske myn-

\section{Hvorfor er kritikk mot den norske deltakelsen $i$ krigen noermest} fravorende når Norge var en del av krigføringen som kritiseres?

digheter at pressen skulle være lojal i saker som angikk Norges forhold til fremmede makter. Avisene aksepterte blant annet telegramsensur under første verdenskrig, og i tillegg deltok redaktørene aktivt i utøvelsen av sensuren for å sikre nasjonens interesser. Lund-kommisjonen dokumenterte pressens nære bånd til de hemmelige tjenestene. Det langvarige samspillet mellom pressefolk og de hemmelige tjenestene begynte under den andre verdenskrig, og det finnes eksempler på at journalister har opptrådt både som politiske journalister og etterretningsagenter. Norsk presseforbund nominerte inntil for noen få år siden journalister til Forsvarets Høgskole. Kritiske røster hevder høgskolens kurs skapte uheldige bindinger og lojalitetsbånd til Forsvaret. Om dette har hatt betydning for hva journalister skriver om militæret er vanskelig å vurdere, men forholdet mellom pressen og Forsvaret ble utfordret under krigen i Afghanistan da journalistene opplevde at informasjon om de norske spesialsoldatene ble holdt tilbake.

\section{Hemmelighold}

Norske spesialstyrker kjempet mot AlQaida i Afghanistan, men hvem spesialsoldatene var og hva slags oppgaver de utførte, var det lite informasjon om. Dagbladet ledet an kritikken mot Forsvarets hemmelighold. Blant politikerne var det spesielt sv som var kritisk til den manglende informasjonen om de norske styrkenes aktivitet i de afghanske fjellene. Partiet etterlyste svar på om det var registrert tap og skader på norsk eller andre lands personell, eller om det var tatt krigsfanger. Daværende forsvarsminister Kristin Krohn Devold nektet å la seg intervjue muntlig da Dagbladet i mars 2002 konfronterte henne med kritikken mot Forsvarets taushet. Hun krevde å få svare skriftlig på kritikken, noe som utelukket muligheten for oppfølgingsspørsmål. Krohn Devold begrunnet hemmeligholdet med hensynet til personellets og nasjonens sikkerhet. Hun mente offentligheten ikke kunne få kjennskap til hva de norske spesialstyrkene gjorde, for ikke å røpe den enkeltes soldats identitet, 

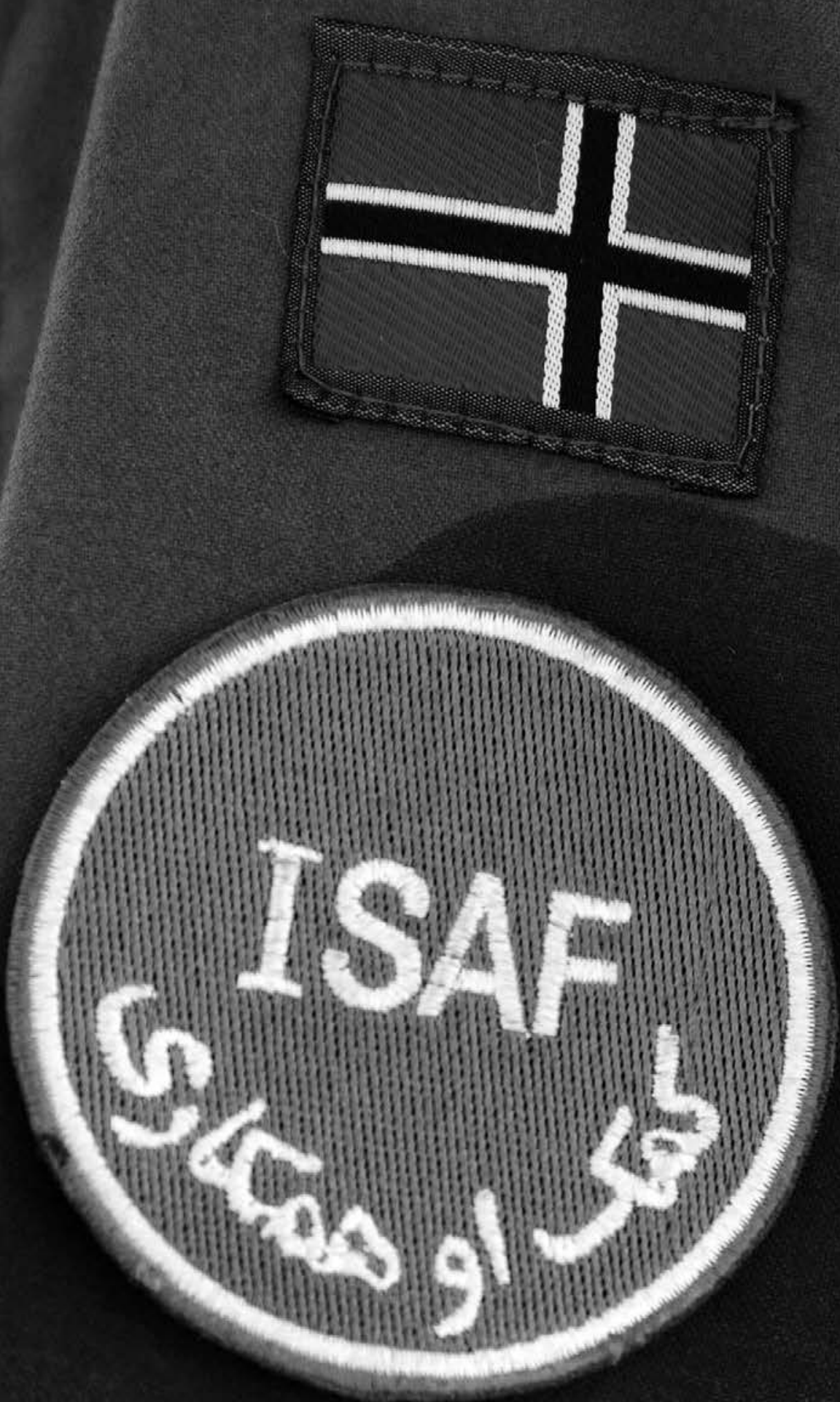
hvor styrkene var lokalisert, deres kapasitet og deres bevegelsesmønstre. Ifølge Krohn Devold veide dette hensynet tyngre enn kravet til offentlighet. I hvilken grad forsvarsministeren hadde rett $i$ at informasjon om spesialstyrkene ville gå på bekostning av personellets og nasjonens sikkerhet, er det vanskelig å gi et entydig svar på, men at hemmeligholdet går ut over pressens behov for informasjon, er det ikke tvil om. Det var først etter at amerikanske myndigheter opplyste at nordmenn var involvert i krigshandlinger, at dette ble bekreftet fra norsk side.

I denne situasjonen, der lite informasjon var tilgjengelig, er det interessant å se hvordan Aftenposten skriver om spesialsoldatene. Min analyse av alle nyhetsartiklene som omhandlet de norske soldatene $\mathrm{i}$ Afghanistan, viser at Aftenposten tydelig gir uttrykk for at Norge deltar med militært personell og utstyr. Avisen giør det dermed klart at styrkene er ute på et reelt krigsoppdrag. Men en nærmere tekstanalyse av artiklene som omhandler de norske spesialstyrkene, viser derimot at språket ufarliggjør nordmennene som krigsaktører.

Før avreise skriver Aftenposten at soldatene øver på "antiterror". Det er uklart hva "antiterror" innebærer, men en oppfatter umiddelbart at formålet er godt. "Antiterror" får indirekte beskrive hva de norske styrkene skal utføre i Afghanistan, og bidrar til å legitimere at Norge sender militære styrker til landet. I senere forsøk på å beskrive hva soldatene gjør i Afghanistan, viser journalistene ofte til hva spesialstyrkene er utdannet til å håndtere og det ramses opp oppdrag som "spesiell rekognosering, offensive operasjoner og militær assistanse". Avisen forklarer at dette innebærer at nordmennene kan utføre etterretning og informasjonsinnhenting, patruljering, rekognosering, eskorte- og vaktoppdrag, sabotasje og rådgivning. Dette er generell informasjon om styrkenes kapasitet, men sier ikke noe konkret om hva soldatene giør i Afghanistan. Dette skyldes først og fremst at journalistene har liten tilgang på konkret informasjon.

Norske myndigheter presenterer de norske spesialsoldatene som kontingenter fra Marinejeger-kommandoen og Hærens jegerkommando med "spesialkompetanse på en rekke områder, blant annet operasjoner under vanskelige vinterforhold". Myndighetene utelater konsekvent å opplyse om styrkenes konkrete oppgaver i pressmeldingene, noe som bidrar til å ufarliggiøre det norske militære bidraget til krigen. Forsvarsministeren betegnet det norske tilbudet til usa som "en skreddersydd pakke for norsk ekspertise innen vinterkrig, transport og rydding av eksplosiver og miner". Aftenpostens journalist fulgte opp med oppsummeringen "USA får plukke fritt fra den norske militære godteposen".

Den uklare definisjonen av de norske soldatenes rolle i utenlandsoppdrag har vært et problem som er blitt reist av soldatene selv, under liknende oppdrag. I forbindelse med krigen i Irak, i 2003, gikk sjefen for de norske styrkene, oberst Tor Helge Moen, ut i mediene og fortalte at soldatene var frustrerte over at de selv opplevde at de hadde vært i krig, mens myndighetene ikke fremstilte det som et krigsoppdrag. Denne debatten var også oppe under NaTos bombing av Jugoslavia i I999, da daværende statsminister Kjell Magne Bondevik ikke ville kalle angrepene for "krig", men omtalte dem som en 
"humanitær intervensjon". Fire år senere måtte Bondevik beklage ordvalget og innrømme at han hadde tatt feil da han ikke ville si at norske F-I6-piloter deltok i krig. Det er grunn til å tro at ordbruken rundt soldatenes rolle også var en problemstilling for soldatene som tjenestegiør i Afghanistan. For selv om Aftenposten viser at de norske soldatene er i krig, kommer

Flere studier viser at sikkerhetspolitikken $i$ et land er reflektert og forsvart $i$ de dominerende nasjonale massemediene.

konsekvensene av handlingene deres i skyggen av deres profesjonalitet og dyktighet. Avisen omtaler de norske spesialsoldatene som "tøffe" og "profesjonelle". De er "eksperter", "internasjonalt anerkjent", "reflekterte" ("ikke Rambo-typer") og de mestrer teknologien. De har bevist at de kan holde ut smerte: I "kalde ugjestmilde strøk" kan de "ligge rolig på ett sted meget lenge uten å bevege seg eller røpe seg for omgivelsene". Spesialsoldatene er vår tids Nansen og Amundsen, skal vi tro Aftenposten:

"Spesialstyrkene blir trent innen alt fra dykking og fjellklatring til fallskjermhopping og språk. De er spesialister på flere typer våpen, og skal kunne boere med seg alt utstyr de behøver til flere ukers operasjoner. Marinejegerne er de siste årene blitt kjent blant annet for å ha gått Grønland på langs, og de har voert både på Nord- og Sydpolen."
Hvorfor fikk retorikken om at "norske soldater er dyktige" dominere Aftenpostens omtale av spesialstyrkene? Jeg vil hevde at myndighetenes hemmelighold rundt hva spesialstyrkene faktisk gjorde i Afghanistan, var medvirkende til at beskrivelsen fikk gjennomslag i Aftenposten. Det er mitt klare inntrykk at både journalistene og kildene kompenserte for mangel på informasjon om hva styrkene faktisk gjorde, ved å fortelle hva spesialstyrkene var trent for, og hva de hadde kapasitet til å giøre.

Aftenpostens journalister gjorde ofte leseren oppmerksom på at de ikke fikk svar på sine spørsmål om spesialstyrkene. Ved å redegjøre for sine metodiske dilemmaer, kan journalistene hjelpe leseren til å forstå hvilke begrensninger som ligger bak de journalistiske uttrykkene. Dette er en tendens som i økende grad, blir benyttet av journalister i dekningen av internasjonale konflikter og kriger. Til tross for at Aftenposten delvis synliggiorde hemmeligholdet, etterlyser jeg en større debatt $i$ avisen rundt mangelen på informasjon.

\section{Selvsensur?}

Mediedekningen av krigen i Afghanistan var preget av at journalistene fikk svært begrenset adgang til krigsområdene. Aldri har journalister blitt nektet adgang til amerikanske tropper i større grad. Samtidig som myndighetene øvde et omfattende press på mediene, førte terrorangrepene mot USA II. september 200 I til en stor grad av selvsensur i amerikanske medier.

Selv mild kritikk av militære, president Bush og usAs utenrikspolitikk ble sett på som tabu. Septemberangrepene var en enorm tragedie for USA, og folk fryktet for 
nasjonens og egen sikkerhet. I slike situasjoner viser det seg at amerikanske journalister er villige til å gi slipp på idealet om en nøytral journalistikk til fordel for patriotisme.

I motsetning til flere amerikanske medier var ikke Aftenposten redd for å kritisere deler av krigføringen. Kritikken var blant annet rettet mot USAS omstridte militærdomstoler og til fangebehandlingen på Guantanamo-basen på Cuba. Sammenliknet med tidligere medieforskning var andelen kritiske artikler til krigen overraskende høy. I en komparativ studie av deknin-

Flere studier viser at sikkerhetspolitikken $i$ et land er reflektert og forsvart $i$ de dominerende nasjonale massemediene.

gen av Golfkrigen i amerikanske og europeiske medier ble det funnet tendenser som tydet på at norske medier prøvde å unngå å bruke usA-kritiske argumenter.

Dette var ikke tilfelle i Aftenpostens dekning av krigen i Afghanistan, men mer interessant er det at avisen ikke satte de negative sidene ved krigføringen i sammenheng med den norske militære deltakelsen i konflikten. Et talende eksempel er at Aftenposten var svært kritisk i sin omtale av hvordan amerikanerne behandlet de afghanske fangene på Guantanamobasen, men var likevel positiv til at norske soldater sto under amerikansk kommando. I januar 2002 offentliggjorde Pentagon bilder av afghanske fanger på Guantanamo. Bildene av knelende fanger i oran- sje kjeledresser og med bind for øynene førte til en storm av protester fra menneskerettighetsgrupper og regjeringer i andre land.

Bakgrunnen for kritikken var at USA avviste at fangene skulle defineres som krigsfanger og dermed beskyttes av Genèvekonvensjonene. Aftenposten gir en vurdering av fangenes status, ved hjelp av Arne Willy Dahl, presentert som ekspert på krigens lover. Selv om Dahl uttrykker at han er spent på hvilke av Genèvekonvensjonens punkter om krigsfanger UsA ville fravike, stiller ikke Aftenpostens journalist spørsmål om hvilke dilemmaer Norge kunne komme opp i under amerikansk ledelse dersom usa brøt konvensjonene. Den samme tendensen ser en i de andre artiklene om fangene på Cuba. Samtlige unngår å nevne den norske debatten.

Hvorfor er kritikk mot den norske deltakelsen i krigen nærmest fraværende når Norge var en del av krigføringen som kritiseres? Er dette et uttrykk for selvsensur slik en så i amerikanske medier? Aftenposten kritiserte til og med kritiske stemmer i Norge for å ødelegge landets forhold til UsA. I en lederartikkel I7. september 200I refser avisen Gunnar Stålsett for å advare mot at usA ville føre et "hevnpeget opplegg” som kunne ramme sivilbefolkningen og skape ekstremisme og fundamentalisme.

Stålsett er ikke den eneste som kritiseres. Statsrådene Torbjørn Jagland og Bjørn Tore Godal beskyldes for å ha skapt uklarhet om Norges holdning internasjonalt. Aftenposten mener de kritiske røstene ødelegger flere tiårs anstrengelser for å skape velvilje for Norge i usA. Aftenpostens motvilje til en debatt om hvordan terrorismen skulle bekjempes, minner om presi- 
dent Bush' budskap: "Either you are with us or you are with the terrorists."

\section{Kildevalg}

Medienes tilgang til kilder har stor betydning for journalistikkens kvalitet. Jo flere kilder journalistene har tilgang til, jo bedre. Det norske militære tilbudet til usa ble offisielt bekreftet $\mathrm{i}$ en pressemelding 30 . november 200I. Ut fra det faktum at kildene, særlig i krigssituasjoner, kan ha egeninteresse av å gi informasjon, er det viktig å avdekke hvem som fikk uttale seg om tilbudet og om noen typer kilder forekommer oftere enn andre. I løpet av den første uka etter at tilbudet ble kjent (I7. desember 200I), var det relativt få navngitte kilder som uttalte seg om hva tilbudet innebar, noe som tyder på at tilgangen til kilder var dårlig.

En sammenliknende studie av Aftenposten, Klassekampen og Dagbladet i den samme perioden viser at alle de tre avisene baserte dekningen på offisielle eller militære kilder. Studien viser også at avisene benyttet flere av de samme sitatene og metaforene i artiklene om det norske tilbudet, noe som forsterker inntrykket av at kildetilgangen var svært begrenset. Av de sju aktuelle artiklene i Aftenposten den første uka var det totalt fire navngitte militære kilder, mens ni politiske kilder fikk uttale seg om tilbudet. Totalt utgjør dette I3 elitekilder. De fleste studier bekrefter bildet av at mediene ensidig baserer seg på elitekilder i en krigssituasjon. Til tross for at det kun er fire militære kilder som er registrert, er det et klart inntrykk at de militære kildene dominerte de første artiklene som presenterte det norske tilbudet til USA. Grunnen til dette er at avisen baserer seg på flere anonyme kilder som i stor grad ser ut til å komme fra enten det amerikanske eller norske militære miljøet. Aftenposten benytter ofte uttrykket "etter det Aftenposten erfarer" eller "etter det Aftenposten forstår” når de ikke kan navngi kildene.

De anonyme kildene fremmet følgende påstander som pekte på at det norske tilbudet ikke innebar at de norske soldatene skulle i krig: I) Tilbudet til usA var kun symbolsk, 2) Det var kun aktuelt å sende norske styrker til en fredsbevarende styrke, og 3) Den norske assistansen vil kun bestå av instruktører i vinterkrig.

Ut fra det en vet i dag om de norske soldatenes deltakelse i krigen i Afghanistan, var påstandene direkte feil, og avisen ga et villedende bilde av Norges rolle i krigen. Til tross for at Aftenposten ga fakta om hva tilbudet innebar, som for eksempel jagerfly, transportfly og militære enheter på bakken, ble betydningen av tilbudet preget av spekulasjoner fremfor bekreftet informasjon. Ved en så utstrakt bruk av anonyme kilder fikk disse kildene stor innflytelse på hvordan det norske tilbudet ble presentert for offentligheten. En slik bruk av anonyme kilder kan sees på som et brudd på det journalistiske ideal, der kildene helst skal navngis. Men i lys av den situasjonen journalistene jobbet under, med få kilder som ville gi konkrete opplysninger, må bruken av anonyme kilder forstås som et forsøk på å trenge gjennom hemmeligholdet.

\section{Angrepet av demonstranter}

I februar 2006 ble ISAF-styrken i Meymaneh i Afghanistan angrepet av demonstranter. Angrepet skal ha vært et utslag av striden rundt trykkingen av Muhammedkarikaturene i den danske avisen JyllandsPosten i september 2005 og den norske 
kristenavisen Magazinet i januar 2006. Demonstrantene angrep leieren med blant annet panservernraketter og granater. Ifølge Forsvaret kjempet nordmennene for livet og skjøt med skarpt mot demonstrantene. Angrepet fikk myndighetene til å understreke at Norge ikke lot seg skremme ut av Afghanistan:

“Det er ikke aktuelt å trekke seg ut av Afghanistan etter gårsdagens hendelser. ISAF vil vore Norges viktigste militcere utenlandsoperasjon $i$ lang tid fremover. Den har et tydelig FN-mandat og den er ledet av NATO. Arbeidet norske offiserer og soldater gjør har fokus på både stabilisering av samfunnet og reform av sikkerhetssektoren. Slik bidrar de direkte til a fremme menneskerettighetene i landet."

Det er vanskelig å være imot at nordmenn skal jobbe for å styrke menneskerettighetene i Afghanistan, men demonstasjonene mot ISAF-leiren viste hvor farlig oppdraget til de norske soldatene kan være. Norge sendte i februar 2006 fire F-r6 fly til ISAF-styrkene. Til tross for at Norge trekker seg ut av den usA-ledede operasjonen Enduring Freedom, skal flyene, ifølge forsvarsminister Anne-Grete Strøm-Erichsen, kunne støtte operasjonen i "nødssituasjoner."

Som jeg har vist, ga Aftenpostens dekning av de norske soldatene i Afghanistan et uklart bilde av hva de norske soldatene faktisk bidro med for å nedkjempe Al-Qaida. De norske soldatene fremstilles som profesjonelle og dyktige, og deres rolle i krigen ufarliggjøres. Spørsmålet er om det norske samfunnet er forberedt på at norske soldater kan bli sendt hjem i likposer, eller at norske soldater kan komme til å drepe sivile. Ut fra det bildet Aftenposten tegner av de norske soldatene og måten norske myndigheter fremstiller deres oppdrag på, tror jeg svaret er nei. Dette er en problemstilling som ikke blir mindre - om og når norske soldater sendes til Darfur og Libanon.

$$
\cdot f \cdot
$$

I "Norske styrker har tatt krigsfanger", ктв, 6. desember 2005 .

2 "Afghanistan-besøk: Petersen møtte norske soldater", i Aftenposten, I2. april 2002.

3 Rossland, Irene Elisabeth: «Den norske militære godteposen. En analyse av Aftenpostens dekning av Norges deltakelse i krigen i Afghanistan», hovedoppgave i journalistikk. Oslo: Universitetet i Oslo, 2006.

4 Woodward, Bob: «Bush at War», New York: Simon \& Schuster, 2002:I5

5 McChesney, Robert W.: "September II and the structural limitations of us journalism”, i Zelizer, Barbie og Allan, Stuart (red.): «Journalism after September II», London og New York, Routledge, 2002:92.

6 ISAF-styrkene var først under britisk ledelse før de fra 2003 ble underlagt NATO-kommando.

7 Tin, Ina: "Norge bryter krigens folkerett i Afghanistan", i Mennesker og Rettigheter, nr. 3, Oslo: Universitetsforlaget, 2002.

8 "Norske soldater i krig i fjerne land", kronikk i Aftenposten, 22. mai 2003 .

9 Tin 2002.

Io Ottosen, Rune: "Fiendebilder i avisenes utenriksdekning: en studie av endringer i fiendebilder i tre norske aviser" i PRIO Report, nr. 2, Oslo: PRIO, I993:53-54.

II Se blant annet: Dijk, Teun A. van: «News analysis: case studies of international and national news in the press», Hillsdale, New Jersey: Lawrence Erlbaum, I988, Nohrstedt, Stig A. og Ottosen, Rune: «Gulf war, national news discourses and globalization. Journalism and the new world order», Vol. I, Göteborg: NORDICOM, 200I, og Kempf, Wilhelm og Luostarinen, Heikki: «Studying War and the Media. Journalism and the New World Order», Vol. 2, Göteborg: NORDICOM, 2002.

I2 Se blant annet: Bennett, Lance W.: "Toward a Theory of Press-State Relations in the United States”, i Journal of Communication, Vol. 40 nr. 2, Spring, New York: Oxford University Press, I990:I03-I25 og Hallin, Daniel C.: «The "uncensored war": the media and Vietnam», Berkeley/ Los Angeles, California: University of California Press, Ltd, I986.

I3 For en nærmere gjennomgang av myndighetenes argumentasjon se Rossland 2006. 
I4 Se for eksempel Eskeland, Ståle: "Krig og fredsbevarende operasjoner: Lovlig, ulovlig eller straffbart?”, Foredrag i Oslo Militære Samfund 6. oktober 2003, Tilgjengelig: http://home.online.no/ ivajoha/nato/Krigogfredsbe varendeoperasjoner.htm

I5 For en bred historisk gjennomgang, se Knightley, Phillip: «The first casualty: the war correspondent as hero and myth-maker from the Crimea to Iraq», London: André Deutsch, 2003.

I6 Av sikkerhetsmessige årsaker sendte ikke Aftenposten journalister inn i krigssonen i Afghanistan, og avisens tilgang til primærkilder og mulighet for observasjon ble derfor begrenset. Avisen kjøpte derimot stoff fra frilansjournalist Åsne Seierstad som bega seg inn på egen risiko.

I7 Ottosen, Rune: “Journalistenes konfliktfylte lojalitet” i Martin Eide (red.) «Til dagsorden! Journalistikk, makt og demokrati», Oslo: Gyldendal akademisk, 200I:I97-227.

I8 Nilsen, Bjørn og Sjue, Finn: «Skjult dagsorden: mediene og de hemmelige tjenestene», Oslo: Universitetsforlaget, 1998 .

I9 Allern, Sigurd: «Kildenes makt: ytringsfrihetens politiske økonomi», Oslo: Pax, I996.

20 "Hun holder tett", i Dagbladet, 23. mars 2002.

2I “Større åpenhet”, leder i Dagbladet, I5. mars 2002.

22 Forsvarsdepartementet: "Norske bidrag i Afghanistan status I. juli 2002", ODIN [online], 2002. Tilgjengelig: http://www.dep.no/fd/norsk/dok/andre_dok/veiled ninger/oIOoII-I20039/dok-bn.html

23 "Norge er klar til kamp for usA", i Aftenposten, I. desember 200I.

24 ibid.

25 "Frustrerte norske soldater", på NRK.no [online], 7. april 2004. Tilgjengelig: http://www.nrk.no/nyheter/innen riks/39I2246.html

26 Forsvarsnett: "Statsministeren gav ærlig svar", Forsvarsnett [online], 2003. Tilgjengelig: http://www.mil.no /start/article.jhtml?articleID=5I49I

27 "Marinejegere klare for aksjon i Afghanistan", i Aftenposten, IO. november 200 I.

28 Eide, Elisabeth: "Warfare and dual vision", i Reading list to the course War and peace journalism, Oslo: Universitetet i Oslo, 2003.

29 Esser, Frank: "Metacoverage of Mediated Wars: Framing the News Media and Military News Management in the Gulf War Coverage of I99I and 2003", foredrag på konferansen Communication: Questioning the Dialogue, New York, 26.-30. mai 2005.

30 Hickey, Neil: “Access denied: Pentagon's war reporting rules are toughest ever", i Columbia Journalism Review [online], January/February, 2002. Tilgjengelig: http://archives.cjr.org/year/o2/I/hickey.asp

3I Hart, Peter og Ackerman, Seth: "Patriotism \& Censorship Some journalists are silenced, while others seem happy to silence themselves", FAIR Fairness \& Accuracy In Reporting [online], nr. November/December, 200I. Tilgjengelig: http://www.fair.org/index.php?page $=1089$

32 Shudson, Michael: "What's unusual about covering politics as usual", i Zelizer, Barbie og Allan, Stuart (red.) «Journalism after September II», London og New York, Routledge, 2002:36-48.

33 Kempf, Wilhelm: "News Media and Conflict Escalation", i Nohrstedt, Stig Arne og Ottosen, Rune (red.) «Gulf war, national news discourses and globalization. Journalism and the New World Order», vol. I, Göteborg: NORDI COM,200I:I49-I74.

34 Tale til Kongressen, 20. september 200I. Tilgjengelig: http://www.whitehouse.gov/news/releases/2001/09/ 20010920-8.html

35 Forsvarsdepartementet: "Norge tilbyr militære styrker til kampen mot internasjonal terrorisme", pressemelding nr.:062/200I, 30. november 200I, Tilgjengelig: http://www.odin.no/fd/norsk/aktuelt/pressesenter/ pressem/oIOoII-070I34/dok-bn.html

36 Wernersen, Camilla: «PS! Vi er i krig», semesteroppgave i "War and Peace Journalism", vår 2005

37 Nord, Lars, Shehata, Adam og Strömbäck: “Från osäker källa. Bevakningen av Irakkriget i svenske medier", i квм:s Temaserie, $\mathrm{nr} 4$, 2003. Tilgjengelig: http://www.krisberedskapsmyndigheten.se/EPiBrows er/Publikationer/кв мs\%2 opublikationsserier/Tema serie/fran_osaker_kalla_temaserie-2003-4.pdf

38 Jeg har kun har sett på kildebruken i én uke, og det kan derfor ikke trekkes den slutning at Aftenposten generelt baserte seg på anonyme kilder.

39 Forsvarsstaben: "Gjennomgang av foreløpig rapport Meymaneh”, pressemelding nr. I2, dato 9. februar 2006, Tilgjengelig:http://www.mil.no/start/aktuelt/presse meldinger/article.jhtml?articleID $=\mathrm{II} 6737$.

40 ibid.

4I Forsvarsdepartementet: “- Klokt håndtert”, ODIN [online], 2006. Tilgjengelig: http://www.dep.no/fd/ norsk/aktuelt/nyheter/oI005I-2IoI67/dok-bn.html

4I "Norske FI6 fly til Afghanistan", nettmøte på vG.no [online], 6. februar 2006. Tilgjengelig: http://tpn.vg.no/intervju/index.php?Inr=687 